DOI 10.18551/rjoas.2019-06.23

\title{
AWOT ANALYSIS IN SMALL-SCALE FISHING MANAGEMENT IN MARINE WATERS OF INDRAMAYU REGENCY
}

\author{
Saudin* \\ Study Program of Coastal Resource Management, Faculty of Fisheries and Marine \\ Sciences, Diponegoro University, Indonesia
}

Bambang A.N., Mudzakir A.K.

Department of Aquatic Resources, Faculty of Fisheries and Marine Sciences, Diponegoro University, Indonesia

${ }^{\star}$ E-mail: siisaudin@gmail.com

\begin{abstract}
AWOT Analysis is a SWOT analysis (Stengths, Weaknesses, Opportunities and Threats) that are integrated into the AHP (Analytical Hierarchy Process). The management of smallscale capture fisheries in the waters of Indramayu Regency is influenced by several integrated approach factors, namely: ecological, social, economic, environmentally-friendly technology, and institutional factors that have not been well structured, so that resource management sometimes overlaps among several development sectors. Based on the matrix of Internal Strategy Factors (IFAS) and External Strategy Factors (EFAS) on the Management of Small Scale Fishing in Indramayu Regency, it was found that the total internal strategy factor (IFAS) was 3.269 with a strength factor value of 2.169 and a weakness factor value amounting to 1,100 so that the difference is 1,069 . While for the value of the total external strategy factor (EFAS) of 2.626, the opportunity factor value is 1.623 and the threat factor value is 1.003 so that the difference is 0.62 . If this value is analyzed in the internal-external matrix (IE) the Management of Small-Scale Fishing in Marine Waters of Indramayu Regency is in quadrant IV (Integrative Strategy) which means that the Management of Small Scale Fishing in the Waters of Indramayu Regency gains strength and opportunity to continue built and grown (integrated).
\end{abstract}

\section{KEY WORDS}

SWOT analysis, management, small scale fishing, marine waters, Indramayu regency.

Some important issues in capture fisheries management are issues on resources, social and economic, and also institutional issues. Issues on resources are on habitat damage, conflict in the use of fishing gear, and issues on the efforts to increase fishing [5]. In the operational context, the issue of resources is also related to technological aspects [7]. While social and economic issues are issues of conflict between fishermen, which is between local fishermen and migrants, the struggle for resources between fishermen using gears with different levels of technology, and other factors. While among economic issues are the low prices of fishery products at the fishermen level. In the assessment of fisheries management systems, ecological, social and economic consequences are equally considered, as well as technological and ethical consequences [6]. While institutional issues include the limited formal role of fishermen groups or Usaha Bersama (Joint Business Groups) in determining fisheries management policies. According to [3], fisheries management with an ecosystem approach (Ecosystem Approach to Fisheries Management) includes: (1) fisheries must be managed at a boundary that has an impact tolerated by ecosystems; (2) ecological interactions between fish resources and their ecosystem must be maintained; (3) Management tools should be compatible for all fish resource distributions; (4) the prudence principles in fisheries management decision making processes; (5) fisheries governance encompasses ecological and human system interests.

Management of fish resources is very closely related to the management of operations 
and the target of fishing. In an effort to utilize capture fisheries resources, fishing activities are the main characteristic in fisheries business. However, aspects of uncertainty in such businesses are high. This uncertainty is caused by fishing businesses that are very dependent on the availability of stocks and the potential fisheries resources which is in high temporal variation especially if the utilization rate has exceeded its potential so that in the end the fish resources will be overexploited. The use of resources should consider its sustainability aspects through the dimensions of planning that must be carried out and then how to do that [2].

Determination of small-scale capture fisheries management strategies in marine waters in Indramayu Regency uses AWOT approach. AWOT is a SWOT analysis (Strengths, Weakneses, Opportunities and Threats) integrated into the AHP (Analytical Hierarchy Process). The purpose of this research is to get results of the analysis related to the information base of the strategic planning processes carried out in order to develop a small-scale capture fisheries management strategy in marine waters in Indramayu Regency.

The study was conducted for five months from April to August 2018. The research was carried out in four coastal regions namely Kandanghaur, Cantigi, Indramayu and Juntinyuat Subdistricts, Indramayu Regency, West Java Province. The map of the research sites can be seen in Apendix 5.

\section{MATERIALS AND METHODS OF RESEARCH}

The variable of this research is the management of small-scale capture fisheries and fishing communities in the coastal area. The method used in this research is the survey method which was quantitatively and descriptively analyzed based on the factors influencing the research. [4] stated that the survey method is an investigation conducted to obtain facts from existing symptoms and find factual information. Furthermore, these factors were analyzed by pairwise comparison method using application Expert Choice 11.

Internal Strategy Factors in the Management of Small-Scale Fishing in Marine Waters of Indramayu Regency which refers to IFAS (Internal Strategic Factors Analysis Summary) include:

(1). Strengths:

a. Use of environmentally friendly fishing gear;

b. The role of formal organizations;

c. Supervision of capture fisheries management;

d. There is government support in managing fisheries resources;

e. Conservation of mangroves and coral reefs;

f. Long coastline.

(2) Weaknesses:

a. The lack of counseling and socialization related to fisheries management;

b. Lack of supervision and facilities for monitoring fishing activities;

c. The low level of education of fishermen;

d. Most fishermen do not carry out the fish auction process at TPI (Fish Auction body);

e. Low participation of fishermen in capture fisheries management;

f. There is a conflict of fishermen, especially users of mini bottom trawlers.

External Strategy Factors in the Management of Small-Scale Fishing in the Marine Waters of Indramayu Regency which refers to EFAS (external Strategic Factors Analysis Summary) include:

(1) Opportunities

a. Sufficient fish resource potential

b. Fisherman compliance

c. Development of mangrove forests as a marine tourism area

d. There is a replacement gear program (replacement)

e. TPI and PPI facilities and infrastructure are quite adequate

f. Regional autonomy 


\section{(2) Threats}

a. Over Fishing;

b. The use of fishing gear that is not environmentally friendly;

c. The existence of extreme weather changes;

d. Decrease in environmental support;

e. The role of formal organizations is not optimal;

f. Competition between fishermen from other regions operating in the marine waters of Indramayu.

The analysis aiming at determining the strategy of small-scale capture fisheries management in Marine Waters of Indramayu Regency was carried out using AWOT analysis which is basically a SWOT analysis (Strengths, Weaknesses, Opportunities, and Threats) integrated into the AHP (Analytical Hierarchy Process) in a purpose of increasing the quantitative information base of strategic planning processes. These factors are then further analyzed using the pairwise comparison method with the ExpertChoice 11 application.

\section{RESULTS AND DISCUSSION}

According to [8] IFAS is a tool for formulating strategies to summarize and evaluate major strengths and weaknesses in functional areas and also becomes the basis for identifying and evaluating relationships in these areas. Based on the results of the calculation of the analysis of internal factors, an IFAS matrix that contains strengths and weaknesses along with the weight and rating can be compiled. The determination of the weight is taken from the AHP results, while the rating is determined by the researcher based on the results of the discussion with the respondents. Discussions with respondents were conducted before and after the respondent filled out the questionnaire. The weight and rating of internal and external factors are then multiplied to obtain a score. The results of the comparison analysis of strengths and weaknesses were obtained using the ExpertChoice 11 application, and the IFAS matrix can be seen in Appendix 1.

Based on the calculation of IFAS matrix in Appendix 1, it was found that the main strength factor affecting internal decision making was the use of environmentally friendly fishing gear with a value of $(0.564)$. The role of formal organizations is the second power with a value of (0.351). The role of the formal organization also influences the small scale capture fisheries management factors that are significant in various matters relating to the lives of fishing communities. One program that has been implemented is the socialization of the use of environmentally friendly fishing gear, the introduction of fish shelter as a step to improve fish habitat and increase the income of fishermen through the use of more than one type of fishing gear in one boat owner known as combine fishing and supervision of marine and fisheries resources through community-based supervision groups. However, considering capture fisheries are open and owned by the public (open access common property) so that the application in the field is very difficult to do, especially in overcoming the pressure of fishing activities from other regions or hitching fishermen. Besides that, the existence of government support in the management of fisheries resources especially capture fisheries has a value of (0.363). The next factor is the supervision of capture fisheries management with a value of (0.260); mangrove and coral reef conservation with a value of (0.303) also influences the decision making process which is a force in order to improve damaged fish ecosystems, inhibit the development of non-environmentally friendly fishing gear (destructive fishing) and increase fishermen's income with marine tourism, fishing and capture fisheries productivity. While the lowest strength factor is to have a long coastline with a value $(0.177)$. This illustrates that the coastline length in Indramayu Regency is an element of strength in the management of small-scale capture fisheries in the waters of the Indramayu Regency. Indramayu Regency has a coastline of $147 \mathrm{Km}$, which is the longest coastline in West Java Province. The potential conditions with the length of the coastline make most people in Indramayu Regency live in coastal areas where their profession in general is as fishermen with capture fisheries. As for the main weakness factor lies in the lack of counseling and socialization related to fisheries management with a value of $(0.312)$. The second weakness 
factor is the lack of supervision and monitoring facilities for capture fisheries activities with a value of (0.244). The third weakness factor is the low level of education of fishermen with a value of (0.189). This shows the low quality of human resources in fishing communities. Based on existing data, the average education of fishermen's husbands and crew members is generally elementary school graduates, while the average wife's education does not graduate from elementary school or under husband's education. This reinforces the notion that community development in the capture fisheries sub-sector faces obstacles in the low quality of human resources and poverty. Furthermore, the fourth weakness factor is the participation of fishermen in the management of capture fisheries which is low with a value (0.159). It is proven that the fishing community in Indramayu Regency has a perception of catch fisheries management is quite high but the implementation in the field and its participation have not been significant or are still relatively low. The fifth weakness factor is the conflict of fishermen, especially arad net users, with a value of (0.114). Based on the results of a research interview, conflicts between fishermen still occur frequently, among fishermen who use mini bottom trawl fishing gear with fishermen who use Gill Net.

This still exists due to the low level of awareness of mini bottom trawl fishermen on fishing operations that are permitted for mini bottom trawling and the lack of supervision and media for surveillance of capture fisheries and law enforcement and regulations that are not yet firm. The weakest weakness was that most fishermen did not carry out fish auction processes at the fish auction site (TPI) with which the value amounting to 0.082 . It is evident that in general small fishermen are still caught in debt given by the broker/middleman which also means that the fishermen cannot have a bargaining position and they finally sell their cpmmodity to the broker. As for the total value of the IFAS matrix is 3.269 (classified as the average position), which means that the internal organization is in a strong position. The IFAS matrix value of the strength factor has a score of 2,169, while the weakness factor has a low score of 1,100 . The difference between the two internal factors is 1.069 . This value means that internal factors in the form of strength have more influential or more dominating values than the current weaknesses.

After obtaining internal factor score (IFAS), it is necessary to make an external factor analysis (EFAS) which includes opportunities and threats in small-scale capture fisheries management strategies in the waters of the Indramayu Regency. Determination of weight is taken from the AHP results while the rating is determined by the researcher based on the results of the discussion with the respondents. Discussions with respondents were conducted before and after the respondent filled out the questionnaire. The weight and rating of external factors are then multiplied to get a score. The results of the comparison of opportunity and threat factors were obtained by the Expert Choice 11 application and the EFAS matrix can be seen in appendix 2. Based on the calculation of EFAS matrix analysis in table 37, it was found that the main opportunity factors identified were fisherman compliance with a value of 0.532 . Based on the results of the research interview, it was found that smallscale fishermen in Indramayu District generally adhered to capture fisheries management regulations, but due to the large number of fishermen in Indramayu Regency added by fishermen from other regions such as Subang, Karawang, Cirebon and Brebes who captured in the marine waters in Indramayu using a small fishing fleet (less than 5 GT) in which it results limited range of cruising areas or over fishing on lane 1 (0-4 nautical miles).

The second opportunity factor is the existence of regional autonomy with a value of (0.448), as mandated in Law No. 32 of 2004 concerning Regional Government. this certainly opens up many business opportunities in the fisheries sub-sector, both capture fisheries, aquaculture, fishery product processing, and salt farmers, through the Office of Fisheries and Marine of Indramayu Regency. Activities carried out by the regional government in this case the Office of Fisheries and Marine Affairs of Indramayu Regency, especially in capture fisheries activities through the office of the Small Fishermen empowerment section (PNK) and Business Development. The activities that have been launched are programs to increase the income of fishing communities, such as: the provision of environmentally friendly fishing equipment, 24 HP (Hourse Power) diesel engines and 5.5 HP gasoline engines, with a converter to change fuel gasoline to gas fuel for fishing boats, installation of fish shelters in 
several coordinate points spread in the waters of Indramayu, procurement of cool boxes, Hand Global Position Systems, training and capacity building for fishermen related to equipment environmentally friendly fishing, ship engine maintenance and diversification of fish processing, fish auction site (TPI) rehabilitation, procurement of 'fish trais', construction of break water and dredging of river mouths in each TPI/PPI (Fsih Landing Port)to facilitate the entry and exit of fishing boats, and installation flares on the right and left of each river estuary that have TPI as a sign of fishing boats entering and leaving. The third opportunity factor is adequate fish resource potential (SDI) with a value of 0.369 . Next is the replacement of fishing gear (replacement) with a value of 0.339 . The facilities and infrastructure of TPI and PPI are sufficient to have a value of 0.168 and the development of mangrove forest as a marine tourism area has a value of 0.142 . As for the main threat factor in the small-scale capture fisheries management strategy in marine waters in Indramayu Regency with a value of 0.237 is the role of formal organizations that have not been optimal. The biggest threat factor illustrates that formal organizations such as the HNSI (Indonesian Fishermen Association) branch of Indramayu, KUB (Joint Business Group), NGOs (Non-Governmental Organizations), POKMASWAS (Supervisory Community Groups) and Fisheries Cooperatives, are still not optimally conducting activities, maintaining, and managing environmental sustainability, especially capture fisheries. The second threat factor is a decrease in environmental carrying capacity with a value of 0.232 . It is evident that the environmental support in marine waters of Indramayu began to decrease due to pollution of both domestic and industrial waste. Indramayu's marine waters have a huge supply of industrial waste in the eastern region with the Balongan Oil Processing Industry in Balongan District and in the western region with steam power plants 1 and 2 (PLTU) in the East Sumuradem Village of Patrol District. In addition, the rise of domestic waste originating from 15 rivers which empties into the sea, namely 1). sewo river, 2) sukahaji river, 3) kalimenir river, 4) eretan river, 5) Sumber mas river, 6) bulak river, 7) cilet river, 8) pangkalan river, 9) bangkir river, 10) karangsong river, 11) Singaraja River, 12) Balongan River, 13) Limbangan River, 14) Dadap River and 15) Tegal Agung River. The estuary of the 14 rivers are all to the sea. The third threat factor is the use of non-environmentally friendly fishing gear with a value of 0,198 . Based on the interview results, it was found that there were still many small-scale fishermen using destructive fishing gear such as arad, garok and dogol in fishing efforts, so that the condition of fish habitat was damaged due to the use of these fishing gear. The fourth threat factor is the existence of extreme weather changes with a value of 0.174 . Changes in extreme weather greatly affect the activities of fishermen in fishing in the sea. Fishermen in Indramayu who have joined a group, cooperative members, and who register to get Fishing Region Information (IDPI) once a week will get SMS from IDPI operators related to weather prediction, wind speed, wave height, and potential fishing to cellphone number registered at the Indramayu Fisheries and Marine Service. This can help fishermen in fishing activities at sea. The fifth threat factor is competition between fishermen from other regions who also fish in the marine waters of Indramayu with a value of 0.112 . This activity is also a threat, especially those who do not use environmentally friendly fishing gear. With the coastline length of $147 \mathrm{Km}$, there are many fishermen from other areas operating in the Indramayu marine area such as fishermen from Cirebon, Brebes, Subang and Karawang Regencies.

The lowest threat factor is over fishing with a value of 0.050 . This illustrates that the waters of Indramayu are potential waters, but because of the large number of fishermen in the north coast of West Java with small fishing fleets $(<5$ GT) which result in limited roaming areas, triggering overcrowding situations (over fishing) on line 1 (0-4 nautical miles). The total value of the EFAS matrix is 2,626 (classified as average), meaning that the external organization is in a strong state. EFAS matrix value of opportunity factors has a score of 1,623 , while the threat factor has a score of 1,003 , where the difference between the two external factors is 0,620 . This value means that external factors in the aspect of opportunity have a more influential value than the threat factor for now. The cumulative value of EFAS matrix is lower than the IFAS matrix, this can explain that internal factors are more control in determining the strategy than the choice of external factors. After finding out the critical 
factors of the IFAS matrix analysis process that explain strengths and weaknesses and EFAS matrix analysis that provides an overview of the opportunities and threats faced, then the next step to do is to combine IFAS and EFAS values using the strategy matrix. The purpose of using the strategy matrix is to obtain a strategy that can determine the direction of further development. The matrix position on the aspect of strategy is obtained by combining the results of the total IFAS matrix score and the total EFAS matrix score. Through the merger, the current position of small-scale capture fisheries management strategies in the waters of Indramayu Regency is known and what strategies must be applied in the future. The IE strategy matrix, can be seen in appendix 3 . Based on the calculation results obtained IFAS value of 3.269 with a strength factor value of 2.169 and a weakness factor value of 1,100 so that the difference is 1.069 . While for the EFAS value of 2.626 with an opportunity factor value of 1.623 and a threat factor value of 1.003 so that the difference is 0.62 . Therefore, the strategy that can be applied is an integrative strategy (quadrant IV) for now. According to [1] quadrant IV is a growing and constructive condition, institutions that are involved in implementing small-scale capture fisheries management strategies in the marine waters of Indramayu get the strength and opportunity to continue to be built and grown (integrated). Based on the SWOT matrix analysis there are four types of strategies that can be explained as follows:

(1). Strategy Strength-Opportunities (SO). The SO strategy is a strategy to use the power that is owned to take advantage of the opportunities that exist. Based on the strengths and opportunities obtained, the first strategy that should be carried out is conducting routine fisheries research, especially research related to fisheries management. This is based on the improvement of the latest data every year regarding the estimation of production data, fishing fleet data, the number of fishing gear, the number of fisheries households (RTP) and so on, which can be used as consideration and sustainable fisheries policies, hence an increase is needed the amount of fundamental and strategic research. The second strategy that can be done is to increase the productivity of fishing with environmentally friendly fishing gear. The strategy is based on the existence of government support which is reflected in the replacement fishing gear program. The third strategy that can be done is the development of mangrove conservation areas and coral reefs. This strategy is caused by the length of the existing coastline so that mangrove conservation is needed for prevention of coastal abrasion. Cendikian Island, Biawak Island and Rakit Island in the marine waters of Indramayu is a Regional Marine Conservation Area (KKLD). The fourth strategy that can be done is to increase TPI / PPI facilities and services. There are 14 TPI / PPI in Indramayu Regency which are spread and are still active, therefore facilities and services need to be improved so that small fishermen are willingly join and auction off their catches at TPI. The fifth strategy that can be done is to strengthen the role of the organization or institutional group of fishermen. The role of the organization greatly influences the success of small-scale capture fisheries management, so it needs to be strengthened and developed. The sixth strategy that can be carried out is integrated management and supervision.

(2). ST Strategy (strength-threats). The ST strategy is a strategy to use strength to avoid threats that come from outside. The most important ST strategy is to limit the number of fishing fleets in critical fishing areas. This strategy is carried out as an effort to preserve existing fish resources. The second strategy is to carry out mangrove rehabilitation, coral reef planting and coral transplantation. This strategy is carried out as an effort to preserve mangroves and coral reefs which until now are still ignored. The third strategy is to process waste from business activities around the coastal area. The strategy was carried out as an effort to reduce the pollution of the Indramayu marine environment. The fourth strategy is the empowerment of fishermen through the provision of stimulant assistance to replace environmentally friendly fishing equipment. The strategy is carried out as an effort to keep the sustainability of the existing fish resources in keep them sustainable. The fifth strategy is strengthening the role and function of formal organizations. The sixth strategy is to improve coordination and establish cooperation with fellow fishermen from other regions and local governments.

(3). Strategy WO (weakness-opportunities). The WO strategy is a strategy that 
minimizes weaknesses by utilizing opportunities. The main WO strategy that can be done is capacity building through counseling and socialization related to fisheries management. This strategy is based on the lack of counseling and socialization related to fisheries management in Indramayu Regency. The second strategy is to increase the human resource capacity and skills of fishermen through training and education. The avoidable dweaknesses of this strategy are the low level of education and participation of fishermen in capture fisheries management. This strategy takes advantage of opportunities in the form of fisherman compliance. While the third strategy is to increase facilities for guidance and supervision activities. This strategy is based on the lack of supervision and means of monitoring fisheries activities. The fourth strategy is to increase community participation related to capture fisheries management. This strategy is based on the low participation of fishermen in capture fisheries management. The opportunity used in this strategy is the development of mangrove forests as a marine tourism area. The fifth strategy is the provision of special loans for low interest and unsecured fishermen. The strategy is based on the majority of fishermen who do not carry out the fish auction process at TPI. Opportunities used in this strategy are adequate TPI / PPI facilities and infrastructure. The sixth strategy is continuous assistance to fishermen regarding fishing operations. The strategy is based on the conflict between fishermen, especially users of the 'arad' net. Opportunities used in this strategy are fisherman compliance, the existence of fishing gear replacement programs and the existence of regional autonomy.

(4). WT Strategy (weakness-threats). The WT strategy is a strategy to reduce weakness and avoid threats. The first strategy that can be carried out is wise and wise management of fish resources. The second strategy is capacity building through counseling related to legal sanctions for using fishing equipment that is not environmentally friendly. The third strategy is to increase the empowerment of fishermen through the diversification of other fisheries. The fourth strategy is to increase the active role of the community in fisheries management in the coastal and marine areas. The fifth strategy is to conduct the auction process in each sales transaction through TPI / PPI. The sixth strategy is to manage and maintain conservation areas by monitoring and providing understanding to fishing communities.

\section{CONCLUSION}

Based on the results and discussion, it can be concluded that ecological factors are the most important factor in managing small-scale capture fisheries, the existence of fish resources in the waters of the Indramayu Regency experiences over fishing. The tendency of over fishing is indicated by the value of MSY (Maximum Supplyable Yield) and the amount of production captured by fishermen from year to year decreases. This is reinforced by the condition of over fishing that occurs due to the actual amount of effort that has exceeded the EMSY value so that a small scale capture fisheries management strategy is needed in marine waters of the Indramayu that gains the strength and opportunity to continue to be built and grown (integrated).

\section{ACKNOWLEDGEMENTS}

The writer would acknowledge to all friends of Fish Instructor Officer (PPB), the administrators and members of the joint business group (KUB), the head of the regional technical implementation unit (UPTD), the Small Fisheries Empowerment Sector (PNK), staff of the Fisheries and Maritime Affairs and Development Agency and regional planning (BAPPEDA) of Indramayu Regency, who has provided data assistance needed by the author so that the study can be completed smoothly.

\section{REFERENCES}

1. Candra, A. 2013. "Strategi Kebijakan Perikanan Tangkap Indonesia dalam Kerjasama 
Perikanan Regional pada West and Central Pasific Fisheries Commission (WCPFC)". (Policy Strategy for Indonesian Capture Fisheries in Regional Fisheries Cooperation at West and Central Pasific Fisheries Commission (WCPFC) Disertasi. Program Pasca Sarjana. IPB. Bogor.

2. Carles. 2014. "Strategi Pengelolaan Perikanan Tangkap Skala Kecil di Perairan Laut Kabupaten Simeulue". (Strategy for the Management of Small Scale Fishing in the Marine Waters of Simeulue Regency). Tesis. Program Pasca Sarjana. IPB. Bogor.

3. FAO (2003). Ecosystems Approach to Fisheries. FAO Tecnical Paper.

4. Kusnandar, M. S. 2015. "Strategi Pengelolaan Sumberdaya Perikanan Berbasis Ekosistem". (Ecosystem-Based Fisheries Resource Management Strategy) J. Oseatek, Vol. 9 (01), 1858 - 4519 hal.

5. Kusnadi, 2002. "Konflik Sosial Nelayan. Kemiskinan dan Perebutan Sumberdaya Perikanan". (Fishermen's Social Conflict. Poverty and the Struggle for Fisheries Resources). LKiS, Yogyakarta. 190 p.

6. Mc Goodwin, J. 1990. Crisis in the World Fisheries: People Problems and Policies. Stanford University Press, Stanford.

7. Monintja, D.R., Sultan, M., dan Sarminto. 2002. "Metode Seleksi Teknologi Penangkapan Ikan yang Ramah Lingkungan dan Berkelanjutan di Kawasan Terumbu Karang". Makalah Konferensi Nasional III Pengelolaan Sumberdaya Pesisir dan Lautan Indonesia. (The Selection Methods Environmental and Sustainable Fishing Technology in the Coral Reef Area. Paper on the Third National Conference on Management of Indonesian Coastal and Ocean Resources) FPIK IPB, Bogor, $15 \mathrm{hlm}$.

8. Supriadi, D. 2012. "Analisis Ekonomi Rumah Tangga Nelayan Skala Kecil dan Pemanfaatan Sumberdaya Perikanan Dasar di Kota Cirebon, Jawa Barat". (Economic Analysis of Small-Scale Fishermen's Households and Basic Fisheries Resource Utilization in Cirebon City, West Java). Disertasi. Program Pasca Sarjana.Universitas Brawijaya. Malang.

APPENDIX 1 - Internal Strategy Factor Matrix (IFAS-Internal Strategic Factors Analysis Summary) Management of Small-Scale Fishing in Marine Waters of Indramayu Regency

\begin{tabular}{|c|c|c|c|c|}
\hline Using emvironmentally friendly fishing gear & \multicolumn{4}{|l|}{141} \\
\hline Role of formal organization &, 134 & & & \\
\hline Government support for fish resources management & 121 & & & \\
\hline Mangrove and coral reefs conservation & ,101 & & & \\
\hline Supervision on capture fishery &, 090 & & & \\
\hline \multicolumn{5}{|l|}{ Lack of counseling and socialization on fishery management ,078 I } \\
\hline Low level of fishermen education & ,063 & & & \\
\hline $\begin{array}{l}\text { Lack of supervision on capture fishery } \\
\text { Having long coastline }\end{array}$ &, 061 & & & \\
\hline $\begin{array}{l}\text { Having long coastline } \\
\text { Fishermen conflict in 'Arad' net }\end{array}$ & ,059 & & & \\
\hline Fishermen conflict in 'Arad' net & ,057 & & & \\
\hline Low participation of fishermen in fishery management & ,053 & & & \\
\hline \multicolumn{5}{|l|}{ Most fishermen did not do the auction in TPI } \\
\hline \multicolumn{5}{|l|}{$\begin{array}{l}\text { Inconsistency: o,05 } \\
\text { With o missing judgments }\end{array}$} \\
\hline \multicolumn{2}{|l|}{ Internal Factor } & weight & Rating & Score \\
\hline \multicolumn{5}{|l|}{ Strength } \\
\hline \multicolumn{2}{|c|}{ a. Use of environmentally friendly fishing gear } & 0,141 & 4 & 0,564 \\
\hline \multicolumn{2}{|c|}{ b. The role of formal organizations } & 0,134 & 3 & 0,402 \\
\hline \multicolumn{2}{|c|}{ c. Supervision of capture fisheries management } & 0,090 & 4 & 0,360 \\
\hline \multicolumn{2}{|c|}{ d. government support in managing fisheries resources } & 0,121 & 3 & 0,363 \\
\hline \multicolumn{2}{|c|}{ e. Conservation of mangroves and coral reefs } & 0,101 & 3 & 0,303 \\
\hline \multicolumn{2}{|l|}{ f. Having a long coastline } & 0,059 & Weakness & 0,177 \\
\hline \multicolumn{2}{|c|}{$\begin{array}{l}\text { g. The lack of counseling and socialization related to fisheries } \\
\text { management }\end{array}$} & 0,078 & 4 & 0,312 \\
\hline \multicolumn{2}{|c|}{ h. Lack of supervision and facilities for monitoring fishing activities } & 0,061 & 4 & 0,244 \\
\hline \multicolumn{2}{|l|}{ i. The low level of education of fishermen } & 0,063 & 3 & 0,189 \\
\hline \multicolumn{2}{|c|}{ j. Most fishermen do not carry out the fish auction process at TPI } & 0,041 & 2 & 0,082 \\
\hline \multicolumn{2}{|c|}{ k. Participation of fishermen in low capture fisheries management } & 0,053 & 3 & 0,159 \\
\hline \multicolumn{2}{|c|}{ f. fishermen conflict especially 'arad' net users } & 0,057 & 2 & 0,114 \\
\hline Total & & 1 & & 3,269 \\
\hline
\end{tabular}


APPENDIX 2 - Matrix of External Strategy Factors (EFAS-External Strategic Factors Analysis

Summary) Management of Small-Scale Fishing in Marine Waters of Indramayu Regency
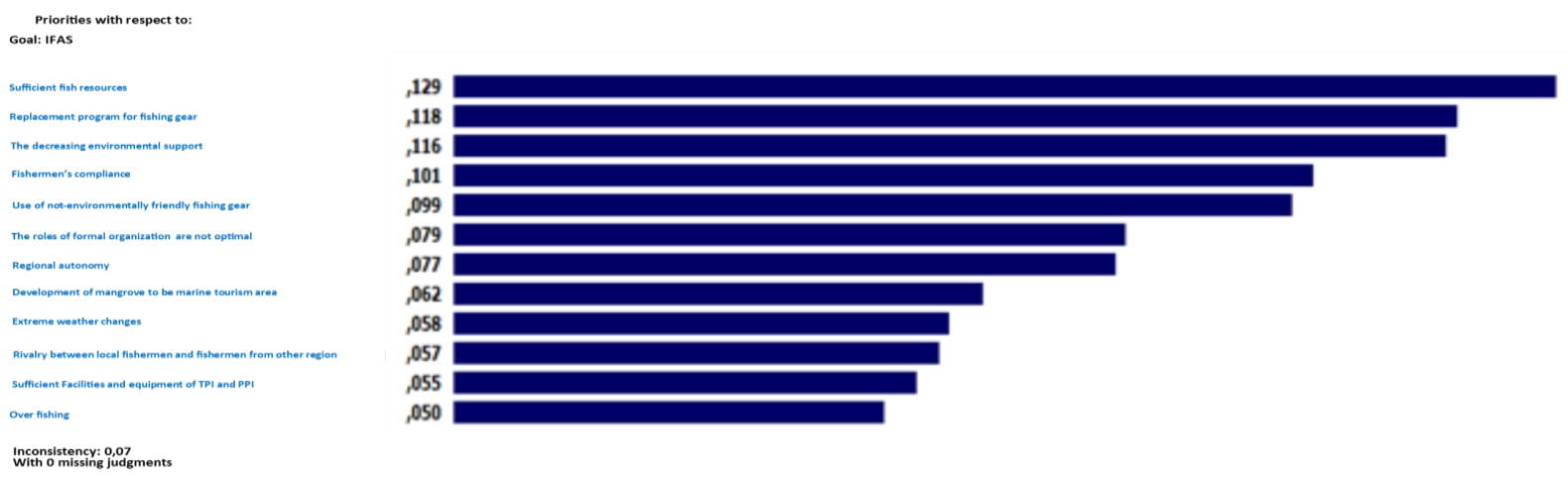

\begin{tabular}{|c|c|c|c|}
\hline External Factor & weight & Rting & Skor \\
\hline \multicolumn{4}{|l|}{ Opportunity } \\
\hline a. sufficient fish resources & 0,129 & 3 & 0,369 \\
\hline b. Kefishermen's compliance & 0,101 & 4 & 0,532 \\
\hline c. Development of mangrove forest marine tourim area & 0,062 & 2 & 0,142 \\
\hline d. Replacement program for fishing gear & 0,118 & 3 & 0,339 \\
\hline e. Sufficient facilities and equipment of TPI and PPI & 0,055 & 2 & 0,168 \\
\hline f. Regional autonomy & 0,077 & 4 & 0,448 \\
\hline \multicolumn{4}{|l|}{ Threats } \\
\hline g. Over Fishing & 0,050 & 1 & 0,050 \\
\hline h. The use of fishing gear that is not environmentally friendly & 0,099 & 2 & 0,198 \\
\hline i. Extreme weather change & 0,058 & 3 & 0,174 \\
\hline j. decreasing environment support & 0,116 & 2 & 0,232 \\
\hline k. the roles of formal organization are not optimal & 0,079 & 3 & 0,237 \\
\hline I. rivalry of local fishermen with those who are from other region & 0,057 & 2 & 0,112 \\
\hline Total & 1 & & 2,626 \\
\hline
\end{tabular}

APPENDIX 3 - Internal Strategy Matrix - External (IE)

Total IFAS Weighted

\begin{tabular}{|c|c|c|c|}
\hline Score & $\begin{array}{c}\text { Strong } \\
(3,0-4,0)\end{array}$ & $\begin{array}{c}\text { Average } \\
(2,0-2,99)\end{array}$ & $\begin{array}{c}\text { Weak } \\
(1,0-1,99)\end{array}$ \\
\hline $\begin{array}{c}\text { High } \\
(3,0-4,0)\end{array}$ & I & II & III \\
\hline $\begin{array}{c}\text { Medium } \\
(2,0-2,99)\end{array}$ & & V & VI \\
\hline $\begin{array}{c}\text { Low } \\
(1,0-1,99)\end{array}$ & VII & VIII & IX \\
\hline
\end{tabular}

APPENDIX 4 - Research Location Map

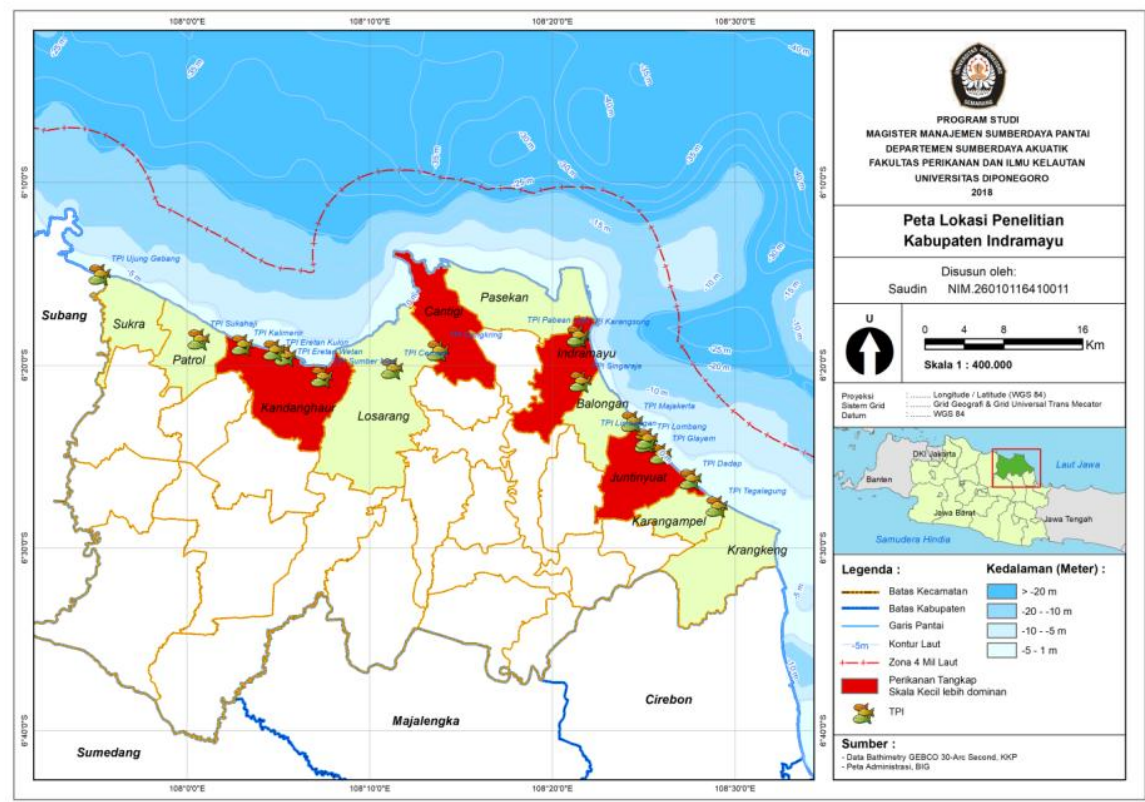


RJOAS, 6(90), June 2019

APPENDIX 5 - SWOT Matrix for Formulating Small Scale Capture Management Strategies

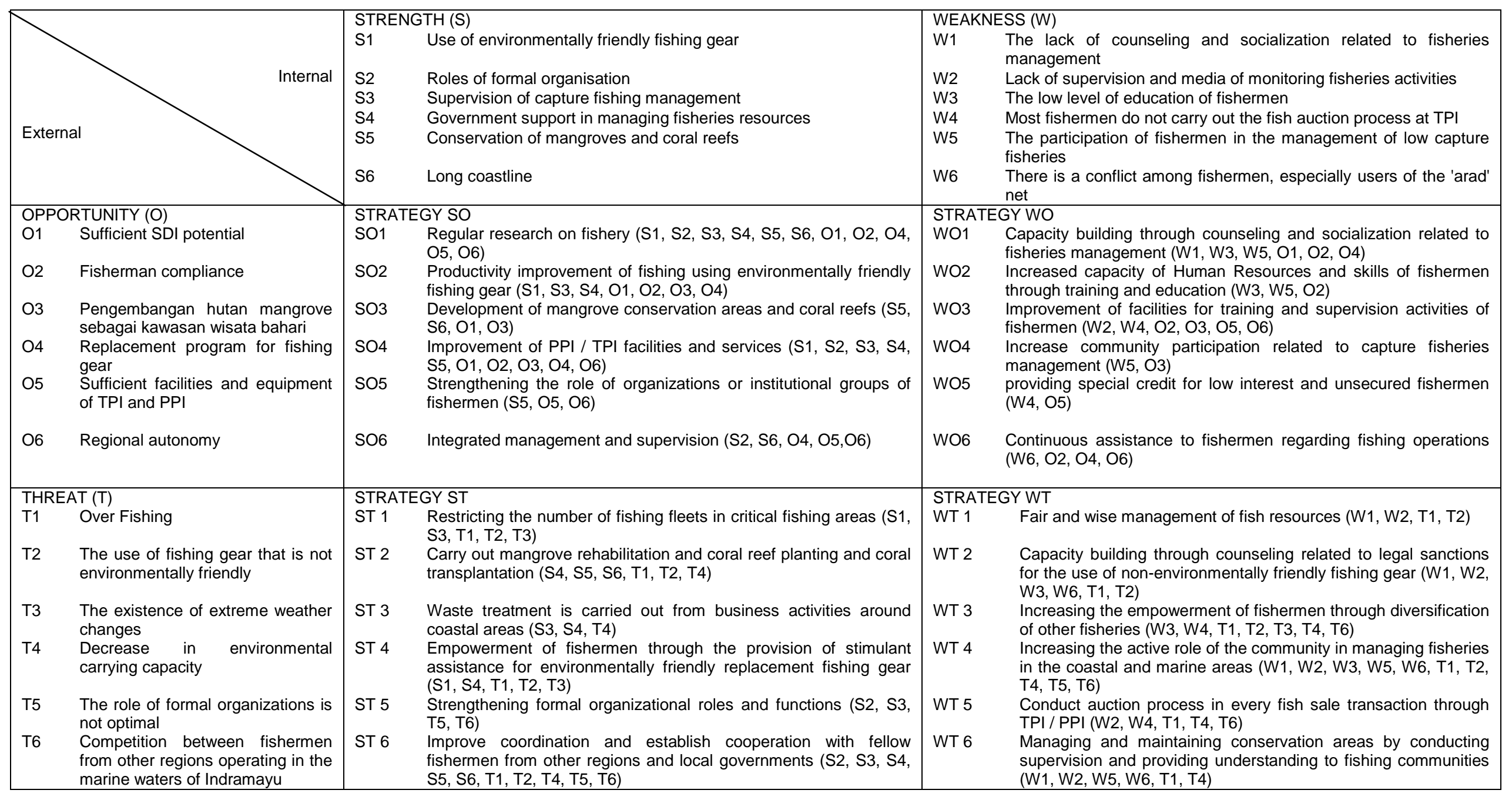

